\title{
MOTERŲ CISTITAS PIRMINĖJE SVEIKATOS PRIEŽIŪROJE
}

\author{
Karolis Lukoševičius, Deividas Rimkus, Vytautas Steponavičius \\ Lietuvos sveikatos mokslu universiteto Medicinos akademijos Medicinos fakultetas
}

Raktažodžiai: cistitas, šlapimo takų infekcija.

\section{Santrauka}

Ūminis nekomplikuotas šlapimo pūslès uždegimas yra viena iš dažniausiai pasitaikančių šlapimo takų bakteriniu infekcijų, kuri kasmet paveikia 150 milijonų žmonių. Šis susirgimas daro didelę ịtaką pacientų gyvenimo kokybei. Tyrimo tikslas - išanalizuoti naujausią informaciją apie cistito etiologiją, diagnostiką, simptomus bei gydymo būdus pirminèje asmens sveikatos priežiūroje. Informacijos paieška atlikta PubMed, BioMed Central duomenu bazèse. Išnagrinèta 14 mokslinių straipsnių, atitikusių atrankos kriterijus. Cistitas yra šlapimo pūslès uždegimas, kurị dažniausiai sukelia šlapimo pūslès infekcija, dažnesnė moterims, nei vyrams. Dažniausias sukèlèjas E. coli nustatomas 86 proc. sergančiujų. Lengvesniais atvejais simptomai ir uždegimas praeina savaime per keletą dienų, tačiau neretai cistito epizodai kartojasi, gali sukelti inkstų geldelių ir inkstų uždegimą ar kitas komplikacijas. Pagrindinis ir dažniausiai pasitaikantis cistito simptomas - nuolatinis noras šlapintis ir deginantis skausmas šlapinantis. Pasireiškus vienam specifiniam cistito simptomui arba esant nespecifinei simptomatikai, patvirtinimui atliekama šlapimo analizè. Išvados. Cistitas yra viena dažniausių infekcijų pasaulyje, sukurianti didžiulius darbo krūvius pirminès asmens sveikatos priežiūros specialistams. Netinkamai gydoma ar nevisiškai išgydyta liga kelia didelę kartotinès infekcijos ir jos atsparumo vaistams riziką. Diagnozė dažnai patvirtinama remiantis simptomais, tačiau nesėkmingo gydymo atveju reikalingi papildomi tyrimai.

\section{İvadas}

Ūminis nekomplikuotas šlapimo pūslès uždegimas yra viena iš dažniausiai pasitaikančių šlapimo takų bakterinių infekcijų, kuri kasmet paveikia 150 milijonų žmonių. Šis susirgimas daro didelę ịtaką gyvenimo kokybei. Sergant ūminiu nekomplikuotu cistitu, diskomfortas jaučiamas apie šešias dienas. Vieno tyrimo duomenimis, apie pusei moterų, kurioms buvo nustatytas ūminis nekomplikuotas cistitas, dèl patiriamų simptomų teko praleisti mokymosi užsièmimus ar darbą. Šis susirgimas atima daug šeimos gydytojo darbo laiko - kiekvienais metais visame pasaulyje apie $10,5 \mathrm{mln}$. vizitų pas gydytoją būna dèl šlapimo pūslès uždegimo simptomų. Dèl dažno ir netaisyklingo antibiotikų vartojimo gydantis ūminị nekomplikuotą cistitą, vis dažniau atsiranda daugeliui antibiotikų atsparių bakterijų [1-2].

Tyrimo tikslas - išanalizuoti naujausią informaciją apie cistito etiologiją, diagnostiką, simptomus bei gydymo būdus pirminès sveikatos priežiūros grandyje.

\section{Tyrimo medžiaga ir metodai}

Informacijos buvo ieškoma moksliniuose darbuose $\mathrm{Pu}-$ bMed, BioMed Central duomenų bazėse. Naudotos raktažodžių kombinacijos: urinary tract infection, treatment of cystitis.

\section{Tyrimo rezultatai}

Etiologija. Ūminį nekomplikuotą cistitą dažniausiai sukelia bakterijos E. coli (86\%), S. saprophyticus (4\%), Klebsiella genties (3\%), Proteus genties (3\%) Enterobacter genties $(1,4 \%)$, Citrobacter genties $(0,8 \%)$, Enterococcus genties $(0,5 \%)$ [3].

Epidemiologija. Moterys kur kas dažniau serga šlapimo takų infekcijomis, negu vyrai. Nuo 40 iki 50 proc. moteru bent kartą yra sirgusios šlapimo takų infekcija, didžioji dalis moteru pirmą kartą susirgo būdamos jaunesnès nei 25 metų. Ši liga dažniausiai pasitaiko 18-24 metų moterims. Nuo 27 iki 46 proc. moterų, sirgusių šlapimo takų infekcija, per metus uždegimas pasikartojo[4-5]. Rizikos veiksniai yra lytinis aktyvumas, spermicidų naudojimas, lytinių partnerių keitimas, cistitu sirgusi motina ir ankstyvame amžiuje prasidèję uždegimai [6].

Simptomai. Yra keletas klasikinių apatinių šlapimo takų infekcijos simptomų - skausmingas deginimas ar perštėjimas šlapinantis, poreikis šlapintis dažniau ir skubiau nei ịprasta, skausmas pilvo apačioje ir hematurija. Jeigu moteriai pasireiške bent vienas ūminis simptomas iš anksčiau minètų, šlapimo takų uždegimo diagnozès tikimybè išauga iki 50 procentų. Tikimybė smarkiai sumažeja, kai kartu su minè- 
tais simptomais pacientė skundžiasi makšties dirginimu ar makšties išskyromis, - tada šeimos gydytojas turètu įtarti vaginitą arba gimdos kaklelio uždegimą. Nesant makšties išskyrų ir dirginimo, bet esant skausmingam ir dažnam poreikiui šlapintis, tikimybė diagnozuoti šlapimo takų infekciją padidejja iki 90 procentų [7-8].

Sirgusioms šlapimo takų uždegimais moterims svarbu žinoti simptomus ir atpažinti susirgimą. Patirtis rodo, kad pasireiškus būdingiems simptomams, dauguma pacienčių supranta, kad vèl prasideda cistitas ir laiku kreipiasi ị gydytoją [3]. K. Gupta ir kitų atliktas tyrimas, kuriame dalyvavo 172 moterys, parode, kad kai kurios moterys, kurios atpažino šlapimo pūslès uždegimą, gali būti saugiai gydomos, susisiekdamos su šeimos gydytoju telefonu. Atsiradus simptomų, 88 moterys pačios nustate sau šlapimo takų infekciją ir gydèsi antibiotikais. Laboratoriniais tyrimais nustatyta, kad net 84 proc. šlapimo mėginių buvo rasta bakterijų, 11 proc. mėginių parodè sterilią piuriją ir tik 5 proc. pasèliu nerasta antigenų [9].

Diagnostika. Cistito diagnozei didžiausią predikcinę reikšmę turi simptomatika - disurija, pakitęs šlapinimosi dažnis ir skubumas, nesant pakitusių makšties išskyrų ir sudirgimo. Ši simptomatika turi didesnę nei 90 proc. prognostinę reikšmę, kuri gali būti grindžiama laboratoriniais tyrimais [1,7,10-13]. Pasireiškus vienam specifiniam cistito simptomui arba esant nespecifinei simptomatikai, patvirtinimui atliekama šlapimo analizè. Tyrimo metu šlapime beveik visada stebima $\geq 10$ leukocitu/ $\mu \mathrm{L}$, o jų neaptikus reikètų itarti kitą diagnozę. Galima atlikti šlapimo tyrimą indikatoriumi. Juo tiriama leukocitų esterazè ir nitritai šlapime, kurie paprastai randami esant Enterobacteriaceae infekcijai. Šis tyrimas naudingiausias pacientams, kuriems pasireiškia tipinė cistito simptomatika ir reikalingas patvirtinimas, tačiau neigiamas testo atsakymas neatmeta diagnozės ir reikètų atlikti detalesnị ištyrimą $[7,10,11]$. Esant atitinkančiai simptomatikai, tačiau neigiamam šlapimo tyrimui indikatoriumi, atipinei simptomatikai arba neveiksmingam empiriniam gydymui 2-4 savaites, atliekamas mikrobiologinis šlapimo tyrimas. Šlapimo kultūra naudinga identifikuoti etiologinį sukèlèją ir parinkti antimikrobini gydymą. Kliniškai reikšmingą bakteriuriją nurodo $\geq 100000 \mathrm{KFV} / \mathrm{ml}$, tačiau $\geq 1000$ augimas laikomas reikšmingu, jei pasèlis gautas kateterizuojant [10,12].

Gydymas. Moterims, kurioms pasireiškia šlapimo takų uždegimo simptomai, tačiau nèra padidejusios temperatūros ir sisteminio uždegimo požymių, rekomenduojama ambulatoriškai vartoti geriamuosius antibiotikus. Klinicistai turètu apklausti pacientus dèl veiksnių, kurie gali turèti itakos antimikrobinio vaisto pasirinkimui: něštumą ir žindymą, kitų vaistų vartojimą, alergijas vaistams, ankstesnę antibiotiku terapiją, keliones. Ankstesnių šlapimo takų uždegimų tyrimų rezultatai turètų būti peržiūrèti, nes jie gali būti naudingi prognozuojant dabartinį sukèlèją ir jo atsparumą vaistams. Pirmos eilès pasirinkimo vaistai: nitrofurantoinas $100 \mathrm{mg} / 2$ k 5 dienas, trimetoprimas-sulfametoksazolas 160/800 mg/2k 3 dienas ir fosfomicinas $3 \mathrm{~g}$ vienkartinè dozè. Antros eilès pasirinkimo vaistai: ciprofloksacinas $250 \mathrm{mg} / 2 \mathrm{k} 3$ dienas ir levofloksacinas $250 \mathrm{mg} / 1 \mathrm{k} 3$ dienas. Moterims, kurių simptomai neišnyksta pasibaigus gydymui, ir toms, kurių simptomai išnyksta, bet vèl pasikartoja, dvi savaites turi būti atliekamas šlapimo pasèlis ir antimikrobinio jautrumo tyrimai. Tokiais atvejais galima manyti, kad infekciją sukeliantis organizmas nėra jautrus iš pradžių naudotam vaistui. Reikia apsvarstyti galimybę pakartotinai gydyti septynias dienas, naudojant kitą vaistą $[13,14]$.

\section{Išvados}

1. Cistitas yra viena dažniausių infekcijų pasaulyje, sukurianti didžiulius darbo krūvius pirminès sveikatos priežiūros specialistams.

2. Netinkamai gydoma ar nevisiškai išgydyta liga kelia didelę kartotinés infekcijos ir jos atsparumo vaistams riziką.

3. Diagnozè dažnai patvirtinama remiantis simptomais, tačiau nesėkmingo gydymo atveju reikalingi papildomi tyrimai.

\section{Literatūra}

1. Flores-Mireles AL, Walker JN, Caparon M, Hultgren SJ. Urinary tract infections: epidemiology, mechanisms of infection and treatment options. Nat Rev Microbiol 2015;13(5):269-284. https://doi.org/10.1038/nrmicro3432

2. RoweTA, Juthani-Mehta M. Urinary tract infection in older adults. Aging health 2013;9(5):519-528.

https://doi.org/10.2217/ahe.13.38

3. Colgan R, Williams M. Diagnosis and treatment of acute uncomplicated cystitis. Am Fam Physician 2011;84( 7):771-776.

4. Kim DK, Kim JH, Lee JY, Ku NS, Lee HS, Park J-Y, Kim JW, Kim KJ, Cho KS. Reappraisal of the treatment duration of antibiotic regimens for acute uncomplicated cystitis in adult women: a systematic review and network meta-analysis of 61 randomised clinical trials. Lancet Infect Dis 2020;20(9):10801088.

https://doi.org/10.1016/S1473-3099(20)30121-3

5. Lala V, Minter DA. Acute Cystitis. Treasure Island (FL): StatPearls Publishing 2021.

6. Geerlings SE. Clinical presentations and epidemiology of urinary tract infections. Urin Tract Infect Mol Pathog Clin Manag 2016:27-40.

https://doi.org/10.1128/9781555817404.ch2

7. Kolman KB. Cystitis and pyelonephritis: diagnosis, treatment, and prevention. Prim Care - Clin Off Pract 2019;46(2):191-202. https://doi.org/10.1016/j.pop.2019.01.001 
8. Korbel L, Howell M, Spencer JD. The clinical diagnosis and management of urinary tract infections in children and adolescents. Paediatr Int Child Health 2017;37(4):273-279. https://doi.org/10.1080/20469047.2017.1382046

9. Gupta K, Hooton TM, Roberts PL, Stamm WE. Patient-initiated treatment of uncomplicated recurrent urinary tract infections in young women. Ann Intern Med 2001;135(1):9-16. https://oi.org/10.7326/0003-4819-135-1-200107030-00004

10. Li R, Leslie SW. Cystitis. Treasure Island (FL): StatPearls Publishing 2021.

11. Hooton TM, Kalpana Gupta. Acute simple cystitis in women. UpToDate 2021. https://www.uptodate.com/contents/acutesimple-cystitis-in-women\#

12. Pietrucha-Dilanchian P, Hooton TM. Diagnosis, treatment, and prevention of urinary tract infection. Microbiol Spectr 2016;4(6):1-20.

https://doi.org/10.1128/microbiolspec.UTI-0021-2015

13. Gupta K, Grigoryan L, Trautner B. In the clinic $($ ) urinary tract infection. Ann Intern Med 2017;167(7):ITC49-ITC64. https://doi.org/10.7326/AITC201710030

14. Kumar S, Dave A, Wolf B, Lerma EV. Urinary tract infections. Disease-a-Month 2015;61(2):45-59.

https://doi.org/10.1016/j.disamonth.2014.12.002

\section{WOMEN'S CYSTITIS AT THE FIRST STAGE OF HEALTHCARE}

K. Lukoševičius, D. Rimkus, V. Steponavičius

Keywords: cystitis, urinary tract infection.
Summary

Cystitis is an inflammation of the bladder that is most commonly caused by an infection of the bladder that bothers women more often than men. The most common pathogen is E. coli, which is detected in $86 \%$ of patients. In milder cases, the symptoms and the inflammation itself improve on their own within a few days, but some people have recurrent episodes of cystitis and need regular and long-term treatment. In some cases, cystitis can cause more serious inflammatory complications of the urinary tract: inflammation of the kidneys and kidneys, so if symptoms do not improve within a few days, a doctor should be consulted. We would probably not confuse the main and most common symptom of cystitis with anything else: the constant urge to urinate and the burning pain when urinating seems to light up a red danger light - inflammation of the bladder. In the presence of one specific symptom of cystitis or in the presence of non-specific symptoms, a urinalysis is performed for confirmation.

Conclusions: 1. Cystitis, one of the most common infections worldwide, is a major workload for physicians in the primary care section. 2. Improperly and incompletely cured disease poses a significant risk of re-infection and the development of drug resistance. 3. Diagnosis is often confirmed on the basis of symptoms, but additional tests should be performed in case of treatment failure.

Correspondence to: lukosevicius.kar@gmail.com

Gauta 2021-04-28

\section{KVIEČIAME PRENUMERUOTI „SVEIKATOS MOKSLŲ“ ŽURNALĄ 2021 METAIS!}

Žurnalas „Sveikatos mokslai“ (Index Copernicus, EBSCO host (Academic Search Complete), Gale (Academic OneFile), ProQuest (Ulrich's, Summon), Australia (ERA) 2012 Journal List (ERA ID 34962) skirtas visų specialybių gydytojams, slaugytojams ir kitiems specialistams, spausdina mokslinius straipsnius lietuvių, anglų kalbomis. Reikalavimai straipsniams atitinka mokslo leidiniams keliamus reikalavimus. Žurnalas spaudos kioskuose neparduodamas. Žurnalą, kuris leidžiamas kartą per du mẻnesius, galima užsiprenumeruoti visuose Lietuvos pašto skyriuose ir internetu: www.prenumeruok.It

Prenumeratos kaina nesikeičia: visiems metams - 36 EUR, šešiems mėnesiams - 18 EUR, keturiems mėnesiams - 12 EUR, dviem mènesiams - 6 EUR. Prenumeratos kodas: 5348.

Žurnalo autoriams straipsnių spausdinimas ir jų internetinė sklaida mokama.

Redakcija 